находилось в момент совершения хищения и у которого оно с помощью обмана изымается. Косвенно такой же точки зрения придерживаются и другие авторы, считая, что обмана уполномоченного работника не происходит, поскольку он не обязан проверять законность правообладания электронным средством платежа.

Таким образом, правоприменительная практика свидетельствует, что криминалистическое содержание стадии способа реализации преступного умысла характеризуется использованием электронных средств платежа. Как правило, с учетом существующей системы их защиты, использование происходит в мелких торговых организациях и на сумму, при приобретении товара на которую не требуется введение пин-кода.

Подводя итог, можно сделать вывод, что состав преступления не позволяет говорить о большом разнообразии криминалистических способов совершения рассматриваемого преступления, которые иногда рассматриваются как способы совершения кражи с банковского счета, а равно в отношении электронных денежных средств. Отсутствие четкого понимания содержания рассматриваемого элемента криминалистической характеристики преступления связано с острой конкуренцией мошенничества с использованием электронных средств платежа и кражи, совершенной с банковского счета, а равно в отношении электронных денежных средств (при отсутствии признаков преступления, предусмотренного статьей 159.3 УК РФ), влекущей за собой квалификационные ошибки, наличие которых влияет на процесс расследования. Поэтому, только при полном изучении, осмыслении и изменении рассматриваемой правовой нормы возможно удовлетворить существующую потребность в выработке криминалистических рекомендаций по выявлению и расследованию мошенничества с использованием электронных средств платежа.

$$
* * *
$$

1. Черных В.В. Проблемы расследования мошенничества, совершенного с использованием банковских карт, и пути их решения // Вестник Таганрогского института управления и экономики. 2018. № 1 (27). С. 123 - 126.

2. Вишнякова А.В. Расследования мошенничеств с использованием электронных средств платежа: выпускная квалификационная работа. г. Челябинск: ЮУрГУ, 2018 г. 88 с.

3. Квасова Е.В. Мошенничество с использованием электронных средств платежа: дипломная работа. г. Тольятти: ТГУ ИП, 2019 г. 76 с.

4. Мазуров И.Е. Методика расследования хищений, совершенных с использованием интернеттехнологий: диссертация. г. Казань: КЮИ МВД РФ, 2017 г. $188 \mathrm{c}$.

5. Харламова А.А. Проблемные вопросы квалификации мошенничества с использованием платежных карт. // Вестник Уральского юридического института МВД России. 2017.

6. Морозова А.О. Проблемы квалификации мошенничества с использованием платежных карт / А.О. Морозова // Инновационные 28 технологии научного развития. Сборник статей международной научно-практической конференции: в 5 частях. - Уфа: Аэтерна, 2017. - С. 135-138.

\title{
Глушко Д.К.
}

К вопросу о порядке заключения договора субподряда: анализ предпосылок и специфических способов заключения

Дальневосточный федеральныий университет (Россия, Владивосток)

doi: $10.18411 / l j-01-2021-133$

idsp: ljournal-01-2021-133

\section{Аннотация}

В данной статье рассматриваются вопросы, связанные с порядком заключения договора субподряда. Автором проанализированы специфические способы заключения договора субподряда. Проводится анализ эффективности способов заключения договора в субподрядных отношениях: общего способа- через оферту и акцепт, а также 
специального - через торги. Помимо этого, были рассмотрены предпосылки заключения договора субподряда.

Ключевые слова: заключение субподряда, договор субподряда, субподряд, предпосылки заключения договора, способы заключения договора субподряда

\section{Abstract}

This article discusses issues related to the procedure for concluding a subcontract agreement. The author has analyzed the specific ways of concluding a subcontract agreement. The analysis of the effectiveness of the methods of concluding a contract in subcontracting relations is carried out: the general method - through the offer and acceptance, and also the special - through the auction. In addition, the preconditions for concluding a subcontract were considered.

Keywords: subcontracting, subcontracting, subcontracting, preconditions for concluding a contract, methods of concluding a subcontracting agreement.

С точки зрения практической значимости вопросы, касающиеся порядка заключения договора, являются актуальными для исследования в рамках рассмотрения любого гражданско-правового договора. Однако, значимость такого исследования существенно возрастает в вопросах, которые не находят прямой регламентации в тексте законодательства. Говоря о порядке заключения договора субподряда, стоит отметить, что в силу производности указанных отношений от основного подряда, к ним применяются общие нормы гражданского законодательства о договоре подряда. Несмотря на это существуют нюансы, о которых можно утверждать после анализа специального законодательства также соответствующей юридической практики. Указанные вопросы будут рассмотрены в данной статье.

Заключение договора является первым этапом возникновения юридических отношений между субъектами. Данный процесс можно охарактеризовать следующим образом: стороны достигают соглашения по обычным и случайным условиям договора в порядке, предусмотренном законодательством. Из положений закона, касающихся требований к сделкам и, в частности, к договорам, можно сформулировать понятие «заключенный договор» - это согласованная в законном порядке воля двух и более лиц, в отношении условий, указанных в законе в качестве существенных и других, облеченная в надлежащую форму.

Проведя анализ судебной статистики по категории дел, касающихся споров о признании договора заключенным, которые доходили до кассационной инстанции и были отменены с 2010 по 2018 года, можно наблюдать рост. Такая прогрессия была отмечена и Верховным Судом Российской Федерации, в связи с чем, в целях обеспечения единства практики применения судами законодательства о заключении и толковании договора было принято постановление с соответствующими разъяснениями.

Отмечается, что соглашение сторон может быть достигнуто путем принятия (акцепта) одной стороной предложения заключить договор (оферты) другой стороны (п. 2 ст. 432 ГК РФ), путем совместной разработки и согласования условий договора в переговорах, иным способом, например, договор считается заключенным и в том случае, когда из поведения сторон явствует их воля на заключение договора ( п. 2 ст. 158, п. 3 ст. 432 ГК РФ).

Из указанной формулировки несложно выделить стадии заключения договора: преддоговорные контакты сторон (переговоры), направление оферты, рассмотрение оферты, акцепт оферты. Как отмечает Суханов Е.А. стадии оферты и акцепта являются обязательными в рамках заключения любого гражданско-правового договора

В подрядных отношениях в последнее время распространена практика привлечения подрядчика, например, из другого региона. В силу чего способ обмена 
документацией (оферта, акцепт оферты) особенно удобен для заключения указанного договора.

Заключение и исполнение договора субподряда непосредственно обусловлено существованием основного договора подряда. Оформление договора субподряда связано с заключением основного договора подряда, и первый может быть заключен только после подписания основного договора. Согласие заказчика по общему правилу на заключение договора субподряда не требуется, если из закона или договора не вытекает обязанность подрядчика выполнить предусмотренную работу лично.

Отметим, что в доктрине выделяют несколько видов предпосылок, предшествовавших заключению договора - это организационно-правовые и формально-юридические. Первая группа предполагает наличие особых требований к участникам правоотношений. В рамках подрядных отношений указанные предпосылки имеют большое значение, так как, например, в договоре строительного подряда в качестве должника может выступать только специализированное лицо, имеющее разрешение на те работы, которые необходимо выполнить по договору. Следовательно, субподрядчик, привлекаемый для выполнения определенной работы, должен отвечать требованиям, предъявляемым к исполнителю той части работ, которые поручил ему генеральный подрядчик.

Можно определить, что формально-юридические предпосылки заключаются в оформлении документации в отношении предмета договора или предварительного соглашения. Стоит отметить, что в рамках гражданского законодательства нет норм, которые бы содержали обязательные требования к утверждению предварительной документации. Данные предпосылки можно найти в специальных нормах федеральный законов, а также подзаконных актов, которые устанавливают требования к предмету договора подряда.

О.Г. Строкова к числу предпосылок заключения договора строительного подряда относит: документ, устанавливающий права на земельный участок; разрешение на строительство. Можно увидеть, что указанные документы в соответствии с Градостроительным кодексом Российской Федерации относятся к исходно-разрешительной документации. Возникает вопрос, является ли такая документация предпосылкой для заключения договора субподряда? Отметим, что исходно-разрешительная документация - это совокупность актов, выдаваемых органами государственной или муниципальной власти, требующихся в обязательном порядке для реализации строительных работ. Такая документация может быть получена заинтересованным лицом (не только заказчиком, но и подрядчиком) также и после непосредственного заключения договора. Таким образом, исходноразрешительная документация не может является предпосылкой заключения договора субподряда.

В данном контексте назревает ещё один вопрос по поводу отнесения к предпосылкам заключения договора утверждение проектно-сметной документации. Г.М. Заяханов дает положительный ответ по этому поводу в отношении договора строительного подряда.

Проанализировав законодательные акты, можно отметить, что проектная документация как основание для выполнения работ необходима только в рамках договора строительного подряда. Так как в рамках бытового подряда не выполняются столь сложные и комплексные работы, законодательством не предусмотрено никаких требований об утверждении проектной документации. Рассматривая подряд на выполнение проектных работ, можно отметить, что данная документация будет являться предметом указанного договора, следовательно, предшествовать его заключению она не может. Так, в соответствии со ст. 759 ГК РФ по договору подряда на выполнение проектных работ заказчик обязан передать подрядчику задание на проектирование. Задание формируется на основе производственной потребности. Сама 
потребность побуждает заказчика в случае невозможности самостоятельного исполнения заключать договор с другим субъектом - подрядчиком. Исходя из этого задание на проектирование можно определить в рамках договора на выполнение проектных работ как предпосылку его заключения.

Рассмотрим проектную документацию как предпосылку заключения договора строительного подряда. В соответствии со ст. 743 ГК РФ договором строительного подряда должны быть определены состав и содержание технической документации, а также должно быть предусмотрено, какая из сторон и в какой срок должна предоставить соответствующую документацию. Проектная документация является частью технической документации, составляющей основу для будущих работ. Таким образом, исходя из буквального толкования можно сделать вывод, что проектная документация, являясь совокупностью актов, оформляющих возникшую у заказчика потребность, может быть сформирована и после заключения договора. А так как заключение проектной документации предшествует составление технического задания, следовательно, именно указанный акт будет являться предпосылкой. Подтверждение данного утверждения можно будет увидеть при рассмотрении специального способа заключения договора - аукциона.

Однако, если рассматривать вышеописанные предпосылки применительно к субподрядным отношениям, необходимо отметить, что несмотря на то, что обязанность по подготовке актов, предшествующих заключению договора, может лежать на заказчике, не являющимся участником правоотношений с субподрядчиком, на основе данной документация также заключается и договор субподряда. На этапе заключения договора между генеральным подрядчиком и субподрядчиком необходимо отразить в содержании обязанность подготовки технической документации, а также срок его предоставления. Так как исполнитель не может приступить к работам в силу их отсутствия.

Рассмотрим специфические черты заключения договора субподряда через классификацию способов заключения, которые подразделяются на общие и специальные. К специальным относится заключение договора во исполнение предварительного договора и заключение договора с применением торгов.

Обратимся к конструкции предварительного договора. Смысл такого договора сводится к тому, что хозяйствующие субъекты приходят к соглашению, по которому добровольно возлагают на себя обязанности в будущем заключить основной договор о передаче имущества, выполнении работы или оказании услуги. При этом законодатель определяет ряд обязательных критериев предварительного договора, которые обусловлены элементами основного договора: зависимость по форме заключения и содержанию. Так, предварительный договор заключается в форме, которая установлена для основного договора, а если форма не установлена, то в письменной форме (в противном случае предварительный договор признается недействительным). Если срок не определен, то основной договор должен быть заключен в течение года с момента заключения предварительного договора.

Отмечается, что для признания предварительного договора заключенным достаточно установить предмет основного договора или условия, позволяющие его определить.

Предварительный договор дает возможность участникам отношений избежать отказа в оплате организационных действий и издержек, которые были произведены в целях реализации предмета будущего основного договора. В данном случае необоснованный отказ в заключении основного договора подряда позволяет не только заявить требование о понуждении к заключению, но и требование о возмещении убытков, которые понесла сторона, например, в связи с подготовкой строительства. Также исполнение предварительного договора может быть обеспечено задатком, неустойкой за уклонение от заключения основного договора. 
Таким образом, применение конструкции предварительного договора дает подрядным организациям возможность установления предварительных хозяйственных связей, в которых взаимно учтены интересы сторон.

Однако, возникает вопрос: подходит ли основной договор подряда под категорию предварительного договора? Если сравнить две категории договоров по временному признаку, можно отметить, что они заключаются до согласования воли по последующему договору. Однако, субъектный состав в рамках предварительного и будущего договора одинаков. Если рассматривать субподрядные отношения, то в рамках основного договора подряда участники - это заказчик и подрядчик. В последующем договоре субподряда субъектный состав меняется, подрядчик встает на место заказчика и именуется как генеральный подрядчик, а в качестве должника в указанном договоре появляется субподрядчик.

Стоит отметить, что на практике предварительный договор субподряда практически не встречается. По нашему мнению, это вызвано тем, что генеральному подрядчику, находясь в зависимости от исполнения обязательств заказчика по основному договору (оплата работ, а также предоставление технической документации), невыгодно обременять себя перед субподрядчиком, так как риск неисполнения обязательств возрастает. Поэтому указанный вид формальноюридической предпосылки не будет являться актуальным в субподрядных отношениях.

Для того чтобы сформировать представление о специфических чертах порядка заключения субдоговора, проведем исследование специального способа заключения договора - проведение торгов. Стоит отметить, что законодательство в области обеспечения государственных и муниципальных нужд предусматривает особый порядок заключения субподрядного договора.

Так в соответствии с Федеральным законом от 05.04.2013 N 44-Ф3 «О контрактной системе в сфере закупок товаров, работ, услуг для обеспечения государственных и муниципальных нужд» существует обязательный для заказчиков норматив по осуществлению закупок у субъектов малого предпринимательства, социально ориентированных некоммерческих организаций (далее - СМП и СОНО). Одним из вариантов выполнения данного норматива является установление обязательного условия о привлечении подрядчиками к исполнению контракта субподрядчиков, соисполнителей из числа СМП и СОНО.

В ч. 1 ст. 30 федерального закона от 05.04.2013 N 44-Ф3 «О контрактной системе в сфере закупок товаров, работ, услуг для обеспечения государственных и муниципальных нужд» устанавливается, что государственные заказчики обязаны осуществлять не менее $15 \%$ от своего годового объема закупок у субъектов малого предпринимательства (далее- СМП) или социально ориентированных некоммерческих организаций (далее- СОНКО).

Согласно п. 5 ст. 30 федерального закона от 05.04.2013 N 44-Ф3 «О контрактной системе в сфере закупок товаров, работ, услуг для обеспечения государственных и муниципальных нужд», если заказчик в тендерной документации устанавливает требование к подрядчику, не являющемся СМП или СОНКО, привлечь к исполнению контракта субъекты малого предпринимательства, то он должен четко отразить объем работ, который должен быть выполнен такими организациями. Объем устанавливается в процентном соотношении от начальной (максимальной) цены контракта.

В данном законе предусмотрены ограничения для привлечения субподрядчиков в области определенных работ. Ранее это относилось к сфере научноисследовательских работ, но с 2017 года запрет коснулся субподряда на строительные работы, перечень которых находится ниже.

Перечень работ включает в себя 34 пункта: подготовительные работы, земляные работы, инженерная подготовка территории, инженерная защита территории, свайные работы, устройство фундаментов и оснований, возведение несущих конструкций, 
возведение наружных ограждающих конструкций, устройство кровли, фасадные работы, внутренние отделочные работы и т.д.

Подрядные торги как специальный способ заключения договора строительного подряда представляют собой форму выявления наилучшего акцепта. Обязанность по проведению подрядных торгов в форме аукциона или конкурса фиксируется лишь при размещении заказов на подрядные работы для государственных или муниципальных нужд при реализации соответствующих инвестиционных проектов, в остальных случаях заказчик самостоятельно решает вопрос о размещении посредством торгов своего заказа.

Таким образом, рассмотрев вопросы, связанные с заключением договора субподряда, можно сделать вывод, что рассмотрение предпосылок заключения договора субподряда позволило нам увидеть процесс формирования предмета указанного договора. Споры по поводу отнесения того или иного документа к формально-юридическим предпосылкам заключения договора субподряда отражаются на формировании неоднозначной судебной практики, которая подтверждает, что стороны не всегда соблюдают требования закона о согласовании предмета в силу неправильности толкования данной нормы. Рассмотрение общего способа заключения - через оферту и акцепт, а также специального - через торги позволило сделать вывод о том, что на данный момент для договора субподряда специфические требования для заключения предусмотрены только в рамках 44-ФЗ. Проведение конкурентных способов выбора подрядчика в современных экономических отношениях набирают популярность. Стоит отметить, что указанные выше ограничения для привлечения субподрядчиков вводятся для наиболее эффективной реализации договоров субподряда, заключаемых с помощью торгов.

$$
* * *
$$

1. Баласян, Р.Р. Заключение, изменение и расторжение договора строительного подряда / Р.Р. Баласян // ACADEMY. 2016. № 11. С. 61-63.

2. Ершов, О.Г. Предварительный договор в строительстве [Электронный ресурс]. Режим доступа: https://justicemaker.ru/view-article.php?id=4\&art=1578 Загл. с экрана.

3. Заяханов, Г.М. Договор строительного подряда в российском гражданском праве. автореф. дис. ... канд. юрид. наук. / Г.М. Заяханов. Екатеринбург, 2009. 28 с.

4. Каримов, М.Р. Правовая характеристика предварительного договора в гражданском праве России / М.Р. Каримов // Российский судья. 2002. N 4. [Электронный ресурс]. Режим доступа: https://centerbereg.ru/b17359.html Загл. с экрана.

5. Мокров, С.Н. Динамика обязательственных отношений сторон, основанных на договоре строительного подряда: автореф. дис. ... канд. юрид. наук / С.Н. Мокров. М., 2008. 42 с.

6. Строкова, О.Г. Юридические предпосылки заключения договора строительного подряда / О.Г. Строкова // Вестник СГЮА. 2015. №4 (105). [Электронный ресурс]. Режим доступа https://cyberleninka.ru/article/n/yuridicheskie-predposylki-zaklyucheniya-dogovora-stroitelnogopodryada Загл. с экрана.

\section{Григорьева Д.Р., Джепбаров Б.А. \\ Альтернативные формы разрешения правовых конфликтов в сфере прав человека и гражданина}

Набережночелнинский институт Казанского федерального университета (Россия, Набережные Челны)

doi: 10.18411/lj-01-2021-134

idsp: ljournal-01-2021-134

\section{Аннотация}

В статье рассматриваются альтернативные формы разрешения правовых конфликтов в сфере прав человека и гражданина. Объектом исследования являются сложившиеся общественные отношения в сфере применения альтернативных форм разрешения правовых конфликтов в России и зарубежных странах. Авторами дана 